\title{
The successional status of sugar maple (Acer saccharum), revisited
}

\author{
Philippe NolET $^{1 *}$, Sylvain DelagRANGE ${ }^{1,2}$, Daniel BoufFARD ${ }^{1}$, Frédérik DoYON $^{1,2}$, Eric FoRGET $^{1}$ \\ ${ }^{1}$ Institut Québécois d'Aménagement de la Forêt Feuillue (IQAFF), 58 rue principale, Ripon, Quebec, J0V 1V0, Canada \\ ${ }^{2}$ Université du Québec en Outaouais (UQO), Lucien-Brault building, 101 rue Saint-Jean-Bosco, Case Postale 1250, succursale Hull, \\ Gatineau, Quebec, J8X 3X7, Canada
}

(Received 28 March 2007; revised version 3 August 2007; accepted 12 October 2007)

\begin{abstract}
Two complementary experimental designs at two contrasting scales (landscape/long term; individual tree/short term) were used for an in-depth evaluation of the successional status of sugar maple (AS: Acer saccharum Marsh.). First, forest disturbances during the 20th century and composition were mapped for two landscapes in the Du Lièvre watershed of southern Quebec. Our results show that, as well as dominating stands in the absence of fire, AS often rapidly developed dominance after fire, especially in the south of our study area. Similarly, a majority of AS-dominated stands clearcut in 1928 continued to be AS-dominated 60 years later. Second, we examined AS seedlings planted under two very contrasting light regimes. AS seedlings showed a combination of traits particularly adapted to tolerate shade under a low light regime. However, owing to a surprisingly high phenotypic plasticity, AS also exhibited efficient development under high light. This suggests the classification of AS as a late-successional species should indeed be revised and that generalist or trans-successional would be a more appropriate designation for this species. We discuss the ramifications of such a status revision, with an emphasis on the implications for its silviculture.
\end{abstract}

landscape / phenotypic plasticity / scale of organization / succession / sugar maple

Résumé - Révision du statut successionnel de l'érable à sucre (Acer saccharum). Deux dispositifs expérimentaux complémentaires, établis à deux échelles différentes (paysage/long terme et individu/court terme), ont été utilisés afin de mieux évaluer le statut successionnel de l'érable à sucre (AS : Acer saccharum Marsh.). D'abord, une cartographie des perturbations et de la composition forestière au cours du $20^{\mathrm{e}}$ siècle a été réalisée pour deux paysages du bassin du Lièvre dans le Sud du Québec. Nos résultats ont démontré qu'en plus de dominer les peuplements en absence de perturbation du couvert, AS établissait souvent et rapidement une dominance dans les peuplements ayant brûlé, et cela, particulièrement dans le paysage le plus au sud de l'air d'étude. De la même façon, une majorité de peuplements dominés par AS et coupés à blanc en 1928 s'est révélée encore dominée par AS à peine 60 ans après coupe. Ensuite, en réalisant le suivi de semis plantés sous deux régimes lumineux très différents, AS a montré un ensemble de caractéristiques particulièrement adaptées à une bonne tolérance à l'ombre. Cependant, grâce à une étonnante plasticité phénotypique, AS a aussi démontré un développement compétitif sous des régimes lumineux plus élevés. L'ensemble de ces résultats suggère donc une remise en question du statut de fin de succession de AS, lequel répondrait mieux à une appellation d'espèce généraliste ou trans-successionnelle. Les implications d'une telle révision sur la sylviculture de cette essence sont discutées.

paysage / plasticité phénotypique / échelle d'organisation / succession / érable à sucre

\section{INTRODUCTION}

One of the most challenging issues for ecologists is the recognition of the implications of scale (of time, space or organization) in the understanding of patterns and processes (e.g., $[10,14,32])$. A typical example of a multiple-scale ecological pattern is the expression of the successional status of a tree species, since it integrates processes from the individual to the landscape scale and over various periods of time (i.e., germination, development, maturation and dispersal) [7, 45]. Several theoretical models describe the succession of vegetation over time (cf. reviews: [3, 22, 28]). These models generally attribute successional status to a species based on the stage of succession (i.e., early, middle or late) at which it finds relative dominance. Successional status is also often attributed using individual tree traits such as seed characteristics, growth rates, physiological leaf traits and stress ac-

* Corresponding author: pnolet@iqaff.qc.ca climation potential $[3,4,6,19]$. For instance, early successional species are generally associated with a high dispersion of light seeds, light-enhanced germination, higher photosynthetic and growth rates, and a high acclimation potential. Conversely, late successional species are associated to relatively restricted seed dispersal, lower growth rates, higher allocation to reserves and a higher shade-tolerance. However, rare are the species that exhibit the whole suite of traits typically associated with their specific successional statuses. Moreover, since it is difficult to weight the relative importance of each of these traits in the overall expression of a species' status, care should be taken designating successional status to a species that expresses traits from contrasting groups.

In deciduous forests of north-eastern North America, sugar maple (AS: Acer saccharum Marsh.) is systematically classified throughout its range as a late-successional hardwood species (e.g., [5, 21, 46]). At least three main factors explain this classification: (i) its longevity [25], (ii) its capacity 


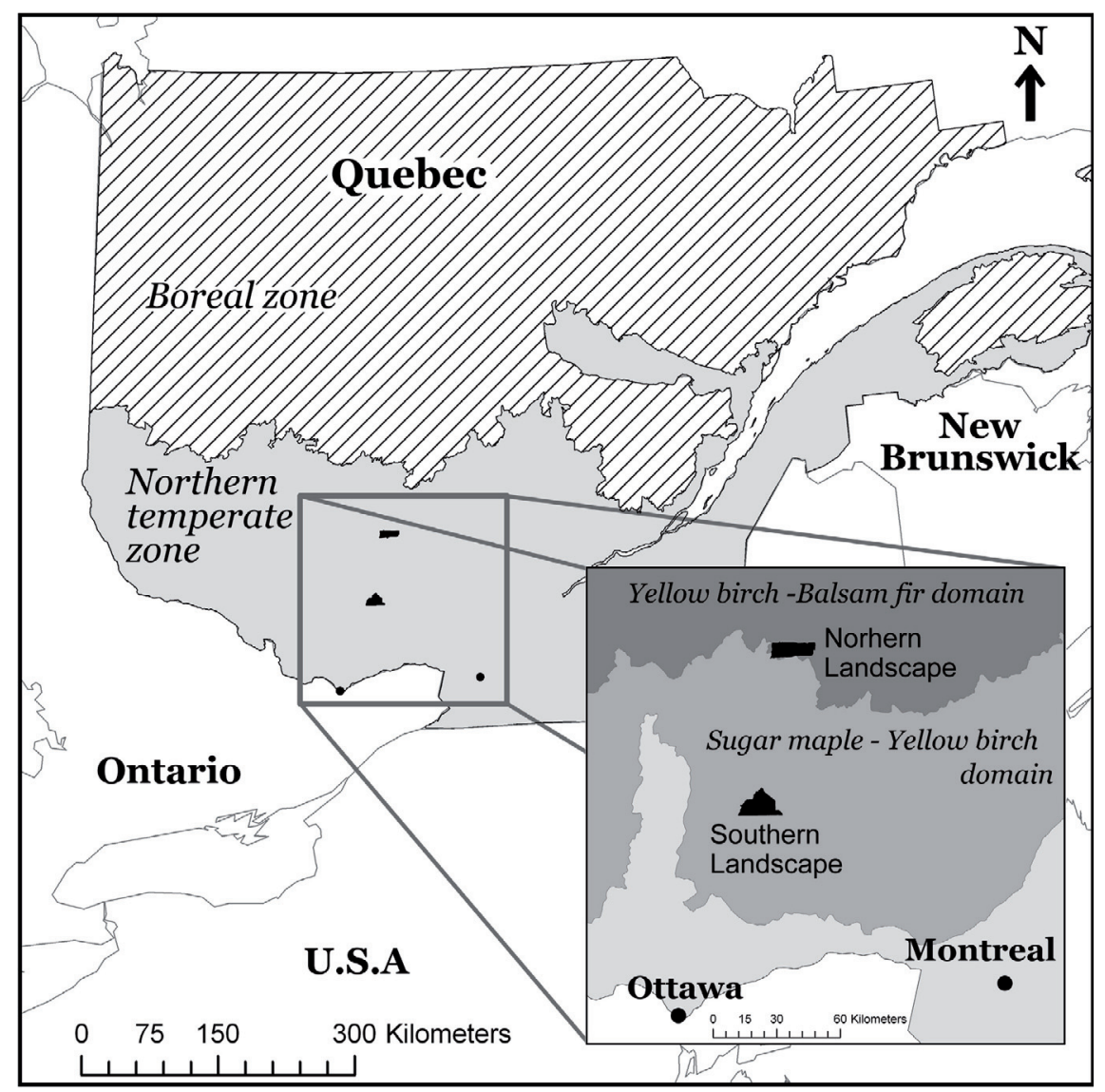

Figure 1. Location of the two study landscapes in southern Québec, Canada. Southern and northern landscapes were approximately 70 km apart and cover 14395 and $12800 \mathrm{~km}^{2}$, respectively.

to regenerate naturally beneath its own canopy [41, 43] and, (iii) its high shade-tolerance $[2,25]$. As a result, AS is often observed to be abundant from seedling to mature canopy tree in late-successional stands $[1,33,41]$. Nevertheless, despite this generalized consensus in the literature, it has been reported that severe disturbances sometimes lead to the development of AS-dominated stands [8, 48]. Furthermore, several studies suggest AS can efficiently use higher levels of irradiance than originally suspected $[9,31]$.

To help reconcile these contradictions, our objective was to evaluate whether AS warrants its late successional status by analyzing information at two contrasting scales: landscape/long term, individual tree/short term. At the landscape scale, given the widely held notion that early successional species should dominate after intense disturbance in temperate deciduous forests to be subsequently replaced by slower growing, middle or late-successional species [13, 27], our first hypothesis is that AS, if present, should be a secondary species in stands that have experienced severe canopy disturbances.

At the scale of the individual, our hypothesis is that AS, as a late successional species, possesses the following characteristics: (i) specific traits well suited to tolerate shading (e.g., a flat crown, higher biomass allocation to leaves and a lower leaf mass per area), (ii) a low acclimation potential of these traits in response to an increase in light availability, and (iii) a low growth potential under higher light regimes [47, 49].

\section{METHODS}

\subsection{Historical reconstructions of landscape composition and disturbances}

\subsubsection{Study area}

Two landscapes in the Du Lièvre watershed of southern Quebec were chosen to examine the transition of forest cover and the disturbances that occurred in hardwood and mixedwood forests since the beginning of the 20th century. The southern landscape occupies 14395 ha, of which $84 \%$ is forested (Fig. 1). Its topography consists of valleys and high hills, with an average elevation of 200$300 \mathrm{~m}$. Thin, undifferentiated tills with rocky outcrops prevail in this landscape, although important glaciofluvial deposits are found in the principal valleys. Climate is characterized by an average annual temperature of 2.5 to $5{ }^{\circ} \mathrm{C}$, by 2600 to 3000 annual degreedays $\left(>5.6{ }^{\circ} \mathrm{C}\right)$, and by $1000 \mathrm{~mm}$ precipitation $(25 \%$ as snow) [42]. Forest cover on mesic sites is dominated by sugar maple and yellow birch (Betula alleghaniensis Britt.). Sugar maple/basswood (Tilia americana L.) stands occur on most fertile sites, whereas sugar 
maple/ironwood (Ostrya virginiana Mill.) stands often occupy hilltops. Yellow birch/balsam fir (Abies balsamea L.) and balsam fir/red maple (Acer rubrum L.) stands typically dominate on lower slopes and valley bottoms.

The northern landscape is located about $75 \mathrm{~km}$ north of the southern landscape (Fig. 1). Its surface area is 12800 ha, of which $83 \%$ is forested. The topography is mostly composed of rounded hills with gentle to moderate slopes and elevations ranging between 200 and $400 \mathrm{~m}$. As in the south, the surficial geology is dominated by thin, undifferentiated tills with abundant outcrops on most uneven hill tops. Mean annual temperature and mean annual precipitations are similar to the southern landscape, with a slightly lower number of annual degree-days (2400-2800) [42]. Current forest cover is dominated by yellow birch/balsam fir and sugar maple on mesic sites and by balsam fir in valley bottoms. Sugar maple-yellow birch stands are present on well-drained, southern exposures as well as on hill tops.

\subsubsection{Landscape characterizations}

Forest cover was characterized using aerial photographs at three different points in time (1928, 1974 and 1990). Photographs from 1928 (1:20000) were used to characterize disturbances for the 19001928 period and cross-validated using maps, harvesting reports and inventories originating from the Maclaren company archives. Photographs taken in 1974 and 1990 (1:15000), in conjunction with harvesting reports, were used to characterize disturbances from 19451974 and from 1974-1990, respectively. No information was available to characterize forest disturbances for the 1928-1945 period. Each disturbance was characterized according to origin (fire, insect outbreaks, windthrow, and harvesting), intensity (percent forest cover after disturbance) and date of occurrence (sometimes identified precisely from historical information and sometimes estimated from aerial photographs). All photo-interpretation was performed according to current Quebec government classification criteria [36] by a professional with 20 years of experience. More than 100 stands were then ground-truthed and none of the stands significantly differed from the characterizations obtained by photo-interpretation.

\subsubsection{Evaluation of forest cover changes}

The overlay of each geo-referenced layer (disturbances and forest cover for the three periods) led to a multiplicity of very small polygons with no ecological significance. Thus, only polygons $>1$ ha were used in the analyses of forest cover changes. We grouped the wide variety of denominations from the photo-interpretation into six main forest cover types (FCT): shade-tolerant hardwood (TH), where sugar maple, yellow birch and American beech (Fagus grandifolia Ehrh.) dominate; shade-intolerant hardwood (IH), where trembling aspen (Populus tremuloides Michx.) and white birch (Betula papyrifera Marsh.) are the main species; mixedwood dominated by hardwood species $(\mathrm{MH})$; mixedwood dominated by conifer species (MC); coniferous species typical of southern Quebec (CS) such as white pine (Pinus strobus L.) and eastern hemlock (Tsuga canadensis L.); and coniferous species typical of the boreal forest (CB) such as black spruce (Picea mariana Mill.) and balsam fir.

To evaluate the effect of fire on forest cover composition, polygons that burned during the 1900-1928 period were selected and the relative frequencies of each FCT within these polygons in 1990 were calculated. It was not possible to test the effect of pre-fire composition on 1990 composition since pre-fire information was not available. To verify the combined effect of harvesting and pre-harvest composition on current FCT, the 1928 and 1990 characterizations were used as starting and ending states, respectively. The 1945-1974 disturbance descriptions allowed the grouping of polygons according to the intensity of disturbance they experienced. Disturbance intensity was divided into three classes: no disturbance (no evidence of altered forest cover), partial cut (more than $25 \%$ of forest cover remaining) and clearcut (less than $25 \%$ of forest cover remaining). The transitions of stands from one type to another were compiled for the three most common 1928 FCT initial states (i.e., TH, MH and MC). The frequency of transition from one state to another was compiled separately for each of the three disturbance types (none, partial cut, and clearcut).

\subsubsection{Persistence of species dominance}

For this analysis, polygons labelled as A. saccharum (AS) and B. alleghaniensis (BA) in 1928 and 1990 were compared. If a species detected in 1928 was still detected in 1990, it was recorded as a confirmed reoccurrence (CR). However, if a species was detected in 1928 but not 1990, it was not taken to mean that it had disappeared from the stand, but rather that it was not abundant enough to appear in the polygon label. At this compositional level, the study focused on understanding how harvesting intensity influenced the CR of both species. To do so, the percentage of CR of AS and BA were compiled according to the harvesting intensity that occurred between 1928 and 1990. Because of the limitations imposed by the photographs' resolution, the qualitative results provided by this procedure inform us primarily of the relative differences in the persistence of AS and BA between harvesting intensities, rather than about absolute differences.

\subsection{Foliar and individual response to contrasting light regimes}

\subsubsection{Plant material and growing conditions}

For this analysis, two contrasting light regimes, high light (HL; $45 \%$ of the global external irradiance) and low light (LL; $8 \%$ of the global external irradiance), were used to study AS foliar and whole tree trait plasticity and to compare this plasticity to trait plasticity of a naturally co-occurring species (i.e., BA). Seeds (provided by the Quebec Ministry of Natural Resources from the Duchesnay forest station, $46^{\circ} 55^{\prime} \mathrm{N}, 71^{\circ} 40^{\prime} \mathrm{W}$ ) of both species were germinated in a greenhouse during the spring of 2001 and, after one month, transferred into $10-\mathrm{L}$ pots filled with a mixture of peat and sand $(1 / 3 \mathrm{v} / \mathrm{v})$. These pots were placed in a nursery at Champenoux $\left(48^{\circ} 44^{\prime} 58^{\prime \prime} \mathrm{N}, 6^{\circ}\right.$ $20^{\prime} 13^{\prime \prime}$ E) near Nancy, France. A combination of aluminized neutral shading nets (OLS screens, Ludvig Svensson, Kinna, Sweden) was used to provide the two contrasting light regimes required. To standardize soil water availability and soil fertility among light regimes, plants were fertilized twice during each growing season (beginning

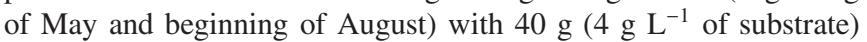
of a slow-release fertilizer (Nutricote ${ }^{\circledR} 100+, 13 / 13 / 13 \mathrm{~N} / \mathrm{P} / \mathrm{K}+$ micronutrients) and water was provided every day to field capacity using timer-controlled drip irrigation. All measurements were taken at the end of the second growing season. Fifteen individuals of each species were placed under each light regime $(n=60)$. 
Table I. Summation of the disturbed area (ha) as a function of investigated periods and disturbance types in each study landscape.

\begin{tabular}{lcccccc}
\hline \multirow{2}{*}{ Period } & \multicolumn{3}{c}{ Southern landscape } & \multicolumn{3}{c}{ Northern landscape } \\
\cline { 2 - 7 } & Partial cut & Clearcut & Fire & Partial cut & Clearcut & Fire \\
\hline $1900-1928$ & 4754 & 447 & 731 & 4393 & 752 & 2813 \\
$1945-1974$ & 2894 & 2467 & 0 & 5698 & 504 & 13 \\
$1975-1990$ & 2131 & 634 & 0 & 3986 & 2571 & 0 \\
\hline
\end{tabular}

\subsubsection{Leaf measurements}

In September 2002, we collected 26 fully developed and well exposed leaves (between six to eight leaves per species and light regime and one leaf by individual) and recorded their area using a planimeter (Delta T devices, Hoddesdon, UK). The leaves were then oven-dried at $60{ }^{\circ} \mathrm{C}$ for $48 \mathrm{~h}$ to measure their dry biomass. Leaf nitrogen content on a mass basis $\left(\mathrm{N}_{\mathrm{m}} ; \mathrm{g} \mathrm{N} \mathrm{g}^{-1}\right.$ leaf dry mass) was determined using an elemental NCS 2500 analyzer (ThermoQuest, Milan, Italy). Leaf mass per area (LMA; $\mathrm{g} \mathrm{m}^{-2}$ ) was obtained by dividing dry leaf mass by leaf area, while leaf nitrogen content on an area basis $\left(\mathrm{N}_{\mathrm{a}} ; \mathrm{g} \mathrm{N}\right.$ $\mathrm{m}^{-2}$ ) was calculated by multiplying $\mathrm{N}_{\mathrm{m}}$ by LMA.

\subsubsection{Crown morphology and biomass partitioning}

In late September 2002, nine AS and BA individuals growing under each of the two light regimes were harvested randomly from the 15 individuals to measure main stem length $(\mathrm{cm})$, crown height (height between the first living branch and seedling top) and crown diameter (mean of the largest diameter and its perpendicular diameter). From these measurements, we calculated the ratio of crown height to diameter (Crown H/D). Finally, roots (coarse: $>2 \mathrm{~mm}$ and fine: $<2 \mathrm{~mm}$ ), main stem, branches, petiole and leaves were separated, dried at $65{ }^{\circ} \mathrm{C}$ for $48 \mathrm{~h}$, and weighed to assess total individual biomass, as well as the relative proportion of each component to the total biomass.

\subsection{Statistical analyses}

ANOVA was used to test for differences in growth, crown morphology, and leaf characteristics among species, light regimes, and their interactions. For Crown H/D and all traits dealing with biomass partitioning in contrasting tree compartment, ANCOVA was performed using main stem length as the covariate. This procedure was used because recent studies have highlighted the importance of individual size or height in the variation of these parameters $[12,16]$; such analyses allowed us to determine if trait differences between light regimes were either light- or size-induced.

\section{RESULTS}

\subsection{Forest cover disturbances}

Almost all fires in both landscapes occurred before 1928 and covered relatively large areas, especially in the northern landscape (Tab. I). Partial cuts were the major anthropogenic disturbances in both landscapes, but clearcuts were also an important disturbance during the 1945-1974 period in the southern landscape and during the 1975-1990 period in the northern landscape.

\subsection{Reconstruction of forest cover changes}

In Figure 2, shade-tolerant hardwood (TH) was the dominant forest cover type (FCT) encountered in both landscapes 70 to 90 years after fires that burned at the beginning of the 20th century (i.e., between 1900 and 1928). This finding was, however, particularly relevant for the southern landscape where the TH stand type represented $57 \%$ of the area burned. Surprisingly, the shade-intolerant hardwood (IH) type was rarely observed after fire, particularly in the southern landscape where this forest type represented only $4 \%$ of the burned landscape (Fig. 2).

Changes in FCT in unburned areas between 1928 and 1990 resulted from the combined effect of harvest intensity, of landscape (i.e., southern or northern) and of pre-harvest FCT (Fig. 3). In the southern landscape, the great majority of the stands classified as TH in 1928 remained as TH in 1990, irrespective of what harvesting intensity they experienced between 1928 and 1990 (Fig. 3A). After clearcut, 92\% of the 1928-TH stands remained as TH in 1990. This percentage was $84 \%$ and $70 \%$ after partial cut and without harvesting, respectively. The decrease in TH type with decreasing harvesting intensity coincided with an increase in occurrence of mixed stands (mixed hardwood (MH) and mixed conifer (MC)). The occurrence of TH stands in 1990 also decreased as a function of initial FCT in 1928; the higher the initial percent cover of conifer, the lower the percentage of TH in 1990. Finally, in the southern landscape, less than $2 \%$ of stands classed as TH, $\mathrm{MH}$ and MC evolved into an IH forest type in 1990, even after clearcutting (Figs. 3A, 3B and 3C).

In the northern landscape, although the patterns were generally similar to those of the southern landscape, several differences were present: (i) $80 \%$ of the stands classed as TH in 1928 remained as TH in 1990, with no correlation with disturbance intensity (Fig. 3D); (ii) the decrease of TH type with the increasing proportion of conifers in initial stands was more pronounced in the northern landscape (Figs. 3E and 3F); (iii) the $\mathrm{TH}$ type in the northern landscape did not generally increase with harvesting intensity (Figs. 3D, 3E, and 3F); and (iv) there was a greater transition into IH stands in the northern landscape compared to the southern landscape, especially in clearcut stands (Figs. 3C, 3D and 3E).

\subsection{Species persistence within stand}

In the southern landscape (Fig. 4A), species-level results indicate that the confirmed reoccurrence (CR) of AS was higher after clearcut $(92 \%)$ and partial cutting $(87 \%)$ than in the absence of harvest $(71 \%)$. However, in the northern landscape, the CR of AS was lowest (38\%) after clearcut but reached about $65 \%$ for the other disturbance types (Fig. 4B). In contrast, for BA, clearcutting resulted in a much lower CR than in the absence of harvest in both landscapes (Fig. 4). Partial cutting showed contrasting effects for the southern and the northern landscapes; in the south, the CR of BA was higher for partially cut stands than for unharvested stands, while the opposite was true in the north (Fig. 4). Overall, the CR of AS 

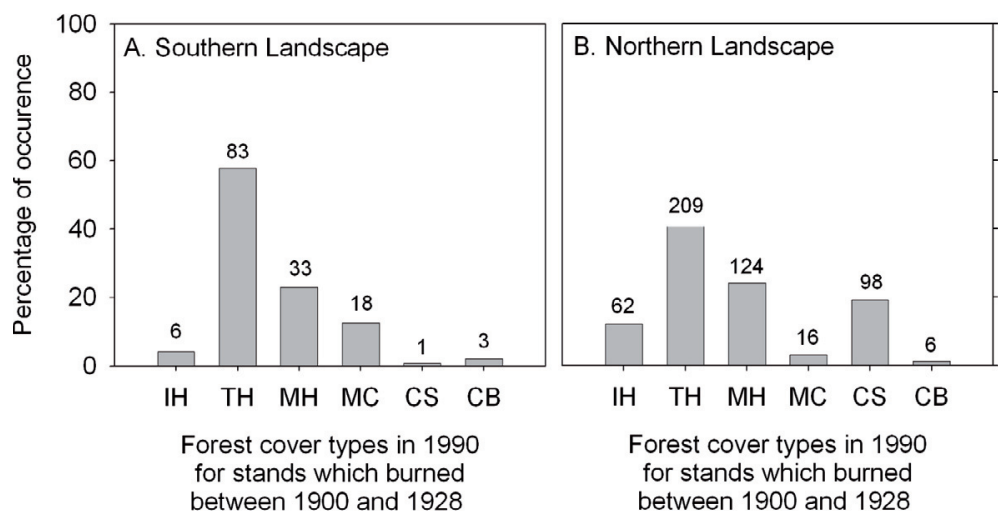

Figure 2. Percentage of forest cover types in 1990 of areas burned before 1928. Forest cover types are IH: shade-intolerant hardwoods, TH: shade-tolerant hardwoods, MH: mixed hardwoods, MC: mixed conifers, CS: conifers typical of southern Quebec and CB: conifers typical of the boreal forest. Numbers of stands used for the computation of the percentages are indicated above the bars.

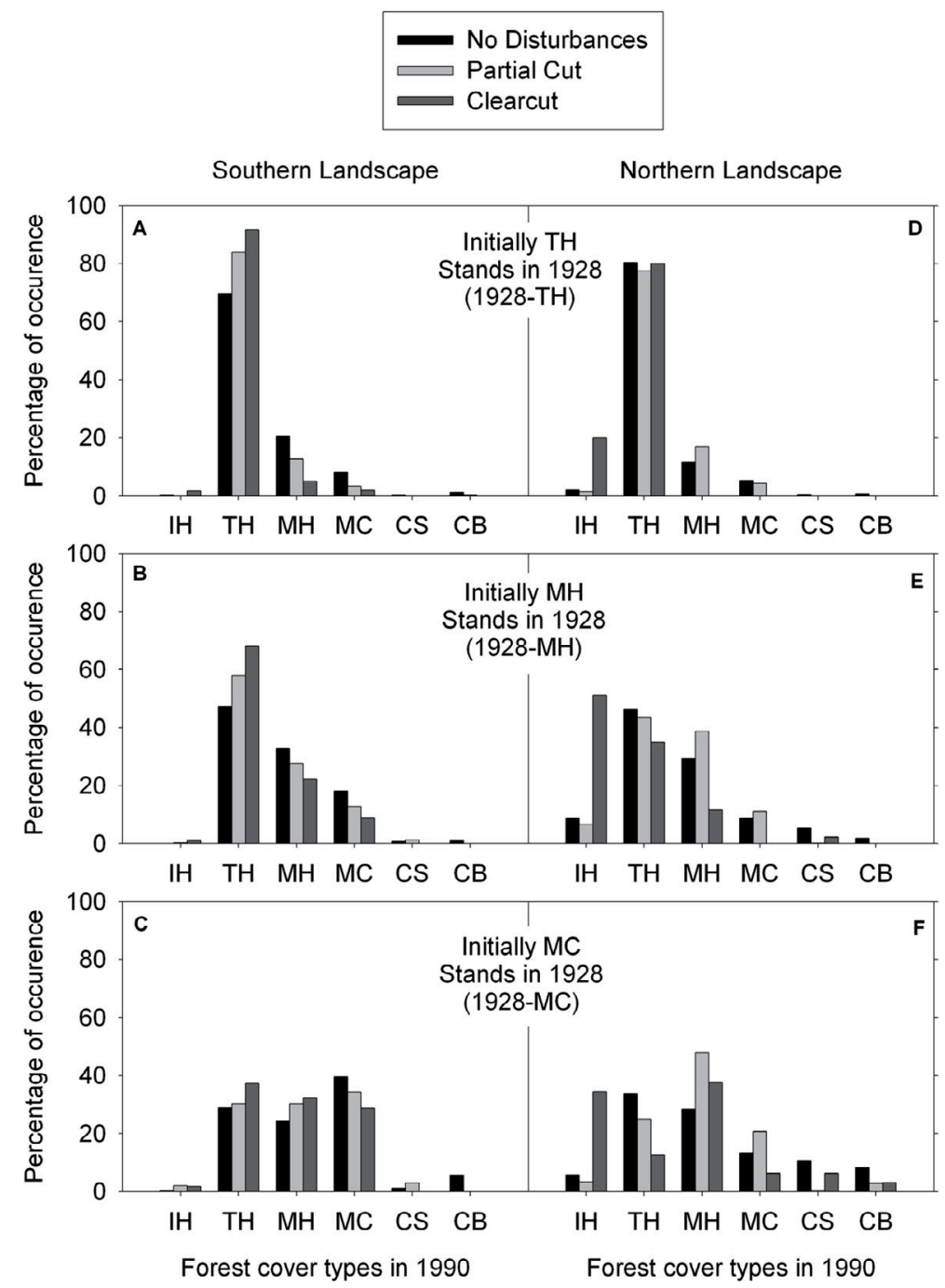

Figure 3. Percentage of forest cover types in 1990 (with no disturbance, and after partial cut or clearcut) for stands that were initially (A and D) shade-tolerant hardwood (TH) stands in 1928, (B and E) mixed hardwood (MH) stands in 1928, and (C and F) mixed conifer (MC) stands in 1928. See Figure 2 caption for cover type descriptions. The number of stands included in the calculation were 1412, 1150, 428, 991, 823 and 498 for the A, B, C, D, E and F graphs, respectively. 


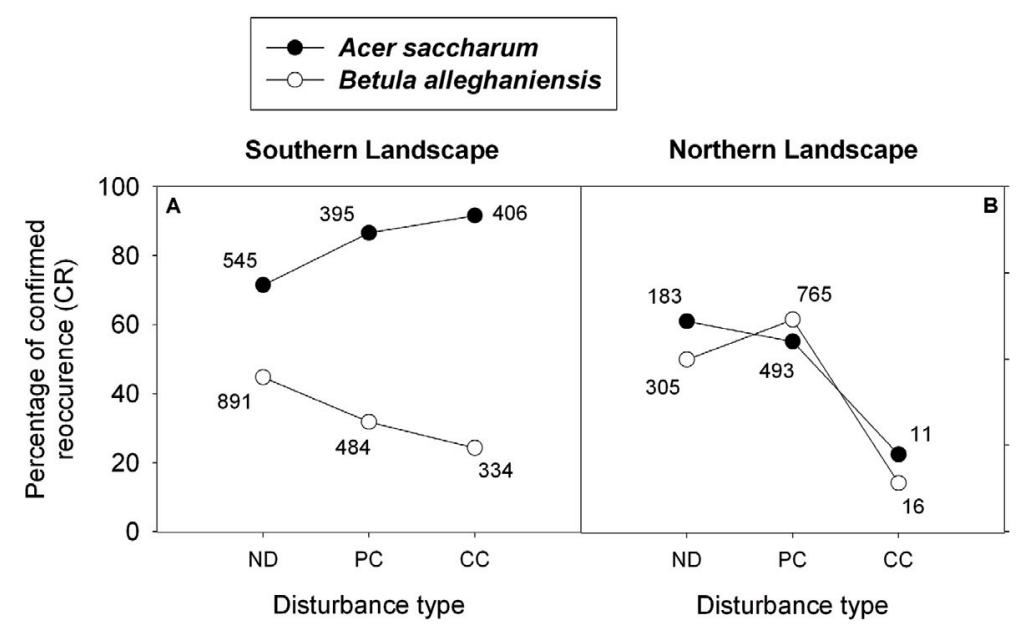

Figure 4. Percentage of confirmed reoccurrence (CR) for Acer saccharum (AS; filled circles) and Betula alleghaniensis (BA; open circles) as a function of disturbance type (ND: no disturbance, PC: partial disturbances; and CC: clearcut). Results for the southern and the northern landscapes are presented separately. Numbers close to the symbols refer to the number of stands included in the percentage calculation.

Table II. ANOVA and ANCOVA results for differences in growth and crown morphology for 2-year old AS and BA seedlings grown under contrasting light regimes: low light ( $8 \%$ of total external radiation) and high light ( $45 \%$ of total external radiation).

\begin{tabular}{lccc}
\hline Source of variation & $d f$ & $\mathrm{~F}$ & $p$ \\
\hline Stem Length & 1 & 1.30 & 0.26 \\
Species & 1 & 236.70 & $<0.01$ \\
Light regime & 1 & 10.10 & $<0.01$ \\
Species $\times$ Light regime & 30 & & \\
Error & & & \\
Total Biomass & 1 & 184.76 & $<0.01$ \\
Stem length & 1 & 0.08 & 0.77 \\
Sp. & 1 & 0.21 & 0.65 \\
LR & 1 & 6.45 & 0.02 \\
Sp. $\times$ LR & 29 & & \\
Error & & & \\
Crown H/D & 1 & 6.83 & 0.01 \\
Stem length & 1 & 1.51 & 0.23 \\
Sp. & 1 & 1.74 & 0.20 \\
LR & 1 & 42.37 & $<0.01$ \\
Sp. $\times$ LR & 29 & & \\
Error & & &
\end{tabular}

was higher in the south than in the north, while the CR of BA was higher in the northern landscape (Fig. 4).

\subsection{Seedling growth, morphology and biomass partitioning in response to light regimes}

For both $\mathrm{AS}$ and $\mathrm{BA}$, the high light (HL) regime greatly increased individual stem length and total biomass (Tab. II, Figs. 5A and 5B). However, the increase in stem length was much higher for AS than BA, resulting in a significant difference between species for stem length as a function of light; under low light (LL), BA was taller than AS, while the reverse was observed under HL (Tab. II and Fig. 5A). A simi- lar trend was observed for total biomass. Despite the fact that total biomass and stem length proved significant covariates, a significant interaction between species and light regimes remained (Tab. II). Thus, even though BA had greater total biomass than AS under LL, no difference between species was apparent under HL (Fig. 5B).

Variation in crown morphology was highly associated with variation of stem length for both species (Tab. II). However, the species showed contrasting responses of crown morphology to light. From LL to HL, the crowns of AS changed from being flat to very long and narrow, while the crown form of BA changed slightly from ovoid to spherical (Fig. 5C).

Patterns of biomass partitioning differed significantly between species, especially in response to contrasting light regimes (Tabs. III and IV). For instance, under LL, AS greatly increased allocation to leaves and petioles (while significantly decreasing its allocation to branches and main stem), as compared to HL. In contrast, BA showed no significant changes in biomass partitioning in response to light (Tabs. III and IV). Biomass partitioning into leaves, branches, and to some extent, coarse roots $(p=0.09)$ was associated with changes in stem length for both species (Tab. IV). No significant difference was found for biomass partitioning into the fine root compartment, either in response to changes in individual size, or between species, light regimes or species-light interactions (Tabs. III and IV).

\subsection{Leaf trait response to light regimes}

For both species, leaf mass per area (LMA) was significantly higher under HL than LL (Tab. V, Fig. 6A). However, no significant differences between species were observed (Tab. V). A similar pattern was observed for leaf nitrogen content on an area basis $\left(\mathrm{N}_{\mathrm{a}}\right)$, although under LL, AS showed a significantly lower $\mathrm{N}_{\mathrm{a}}$ when compared to BA (Tab. V and Fig. 6B). Nitrogen content on a mass basis $\left(\mathrm{N}_{\mathrm{m}}\right)$ significantly 


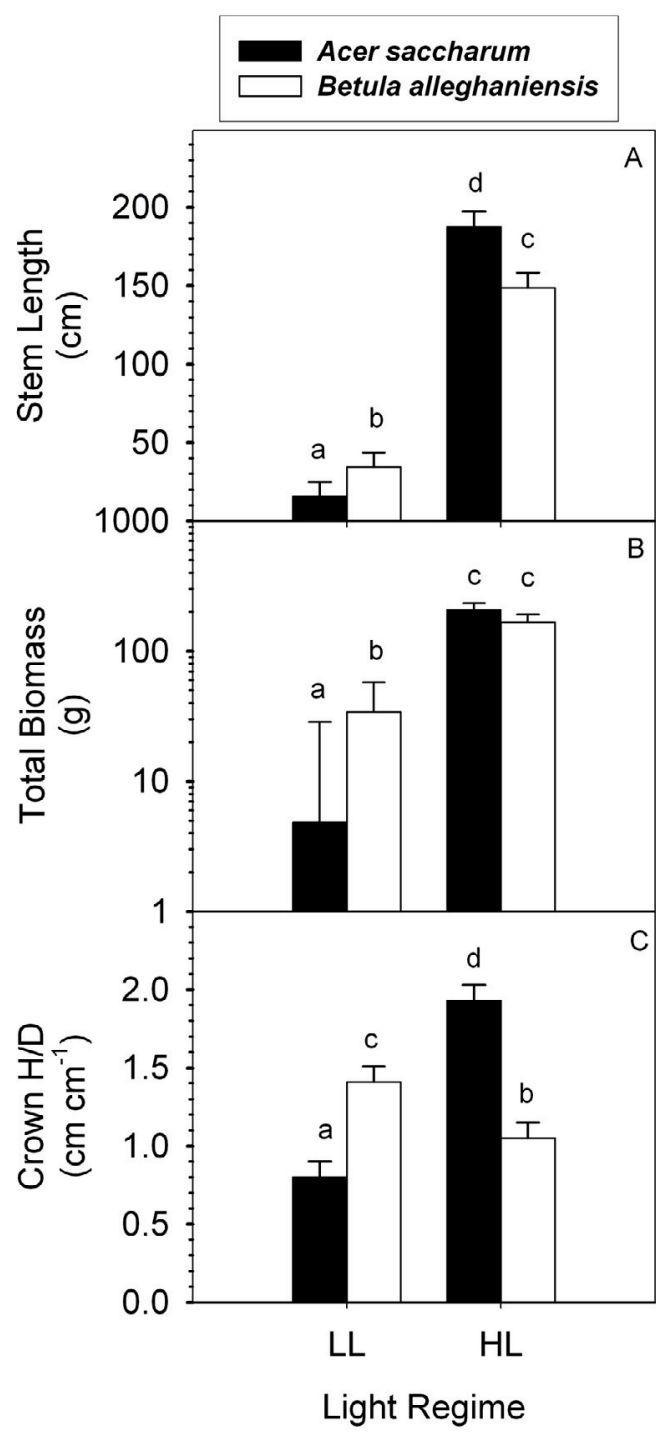

Figure 5. Mean and standard error for stem length (A), total biomass (B) and crown H/D (C) of 2 year-old Acer saccharum (AS; filled bars) and Betula alleghaniensis (BA; open bars) seedlings grown under two contrasting light regimes (low light (LL): $8 \%$ of external radiation and high light (HL): $45 \%$ of external radiation).

varied between light regimes, being higher under the LL compared to HL, but no significant differences were observed between species (Tab. V and Fig. 6C).

\section{DISCUSSION}

\subsection{Disturbance effects on forest composition}

Fire is widely recognized as favouring the development of pioneer species such as Populus, Betula and Pinus species [48]. We found no literature that reported the return of shadetolerant hardwood species such as AS after fire. In this study, the shade-tolerant hardwood $(\mathrm{TH})$ type (largely dominated
Table III. Means and standard errors for biomass partitioning in different compartments of 2-year old Acer saccharum (AS) and Betula alleghaniensis (BA) seedlings grown under two contrasting light regimes: low light (LL; $8 \%$ of total external radiation), and high light (HL; $45 \%$ of total external radiation). Superscript letters indicate significant differences (at $\alpha=0.05$ ) between means of a given row (i.e., within a given parameter).

\begin{tabular}{lccccccccc}
\hline Species & \multicolumn{4}{c}{ BA } & \multicolumn{4}{c}{ AS } \\
\hline Light Regime & \multicolumn{2}{c}{ LL } & \multicolumn{3}{c}{ HL } & \multicolumn{2}{c}{ LL } & \multicolumn{3}{c}{ HL } \\
\hline Parameter & mean & se & mean & se & mean & se & mean & se \\
Leaf \% & $31.81^{\mathrm{b}}$ & 3.90 & $23.97^{\mathrm{b}}$ & 2.43 & $50.57^{\mathrm{a}}$ & 4.28 & $21.4^{\mathrm{b}}$ & 2.46 \\
Petiole \% & $0.03^{\mathrm{b}}$ & 0.01 & $0.02^{\mathrm{b}}$ & 0.01 & $5.00^{\mathrm{a}}$ & 1.15 & $1.78^{\mathrm{b}}$ & 0.45 \\
Branch \% & $12.61^{\mathrm{c}}$ & 3.24 & $18.01^{\mathrm{c}}$ & 0.86 & $0.03^{\mathrm{a}}$ & 0.03 & $3.84^{\mathrm{b}}$ & 1.50 \\
Main Stem \% & $26.80^{\mathrm{b}}$ & 2.16 & $22.36^{\mathrm{ab}}$ & 0.86 & $17.12^{\mathrm{a}}$ & 2.52 & $48.05^{\mathrm{c}}$ & 3.10 \\
Coarse Root \% & $19.85^{\mathrm{ab}}$ & 1.26 & $26.69^{\mathrm{b}}$ & 2.64 & $15.24^{\mathrm{a}}$ & 2.06 & $19.09^{\mathrm{ab}}$ & 1.26 \\
Fine Root \% & $8.90^{\mathrm{a}}$ & 1.65 & $8.97^{\mathrm{a}}$ & 0.95 & $12.04^{\mathrm{a}}$ & 4.65 & $5.85^{\mathrm{a}}$ & 0.81 \\
\hline
\end{tabular}

Table IV. ANCOVA results for differences in biomass partitioning among different compartments of 2-year old Acer saccharum and Betula alleghaniensis seedlings grown under two contrasting light regimes: low light (8\% of total external radiation) and high light (45\% of total external radiation). Among the sources of variation, $\mathrm{Sp}$. refers to species while LR refers to light regimes.

\begin{tabular}{lccccccc}
\hline $\begin{array}{l}\text { Source of } \\
\text { variation }\end{array}$ & $d f$ & $\mathrm{~F}$ & $p$ & $\begin{array}{c}\text { Source of } \\
\text { variation }\end{array}$ & $d f$ & $\mathrm{~F}$ & $p$ \\
\hline Leaf \% & \multicolumn{7}{c}{ Main Stem \% } \\
Stem length & 1 & 4.57 & 0.04 & Stem length & 1 & 0.61 & 0.44 \\
Sp. & 1 & 8.10 & $<0.01$ & Sp. & 1 & 10.14 & $<0.01$ \\
LR & 1 & 0.02 & 0.90 & LR & 1 & 1.35 & 0.25 \\
Sp. $\times$ LR & 1 & 2.99 & 0.09 & Sp. $\times$ LR & 1 & 37.80 & $<0.01$ \\
Error & 29 & \multicolumn{7}{c}{ Error } & 29 \\
Petiole \% & & \multicolumn{7}{c}{ Coarse Root \% } \\
Stem length & 1 & 0.19 & 0.66 & Stem length & 1 & 3.07 & 0.09 \\
Sp. & 1 & 26.18 & $<0.01$ & Sp. & 1 & 13.33 & $<0.01$ \\
LR & 1 & 0.17 & 0.68 & LR & 1 & 0.44 & 0.51 \\
Sp. $\times$ LR & 1 & 3.70 & 0.05 & Sp. $\times$ LR & 1 & 2.53 & 0.12 \\
Error & 29 & \multicolumn{7}{c}{ Error } & 29 & & \\
Branch \% & & \multicolumn{7}{c}{ Fine Root \% } \\
Stem length & 1 & 4.33 & 0.05 & Stem length & 1 & 0.28 & 0.60 \\
Sp. & 1 & 58.75 & $<0.01$ & Sp. & 1 & 0.01 & 0.91 \\
LR & 1 & 1.22 & 0.28 & LR & 1 & 0.01 & 0.90 \\
Sp. $\times$ LR & 1 & 2.02 & 0.17 & Sp. $\times$ LR & 1 & 0.53 & 0.47 \\
Error & 29 & \multicolumn{7}{c}{ Error } & 29 \\
\hline
\end{tabular}

by AS) was much more frequent after fire than the shadeintolerant hardwood (IH) type. As mentioned previously, no information was available regarding composition of the burned areas before fire, or on the relative intensity of the fires. However, the fires occurred in years that were reportedly intense fire years. Furthermore, since forest fires are reported to be typically bottom-up disturbances that burn the understory before moving into the canopy [35], it would be surprising that established AS seedlings or saplings survived the fires and thereby allowed AS to dominate quickly the burned areas. Therefore, the TH type observed in 1990 likely originated from new AS cohorts initiated by stump sprouting, seed rain from adjacent stands, or legacy seed trees. 
Table V. ANOVA results for differences in leaf characteristics for 2-year-old Acer saccharum and Betula alleghaniensis seedlings grown under two contrasting light regimes : low light (LL; $8 \%$ of total external radiation) and high light (HL; $45 \%$ of total external radiation). Among the sources of variation, Sp. refers to species while LR refers to light regimes.

\begin{tabular}{lccc}
\hline Source of variation & $d f$ & $\mathrm{~F}$ & $p$ \\
\hline LMA & 1 & 0.6 & 0.44 \\
Sp. & 1 & 128.3 & $<0.01$ \\
LR & 1 & 1.5 & 0.24 \\
Sp. $\times$ LR & 22 & & \\
Error & & & \\
$\mathbf{N}_{\mathrm{a}}$ & 1 & 0.6 & 0.46 \\
Sp. & 1 & 65.1 & $<0.01$ \\
LR & 1 & 5.9 & 0.03 \\
Sp. $\times$ LR & 22 & & \\
Error & & & \\
$\mathbf{N}_{\mathrm{m}}$ & 1 & 2.3 & 0.15 \\
Sp. & 1 & 7.7 & 0.01 \\
LR & 1 & 0.6 & 0.81 \\
Sp. $\times$ LR & 22 & & \\
Error & & &
\end{tabular}

In contrast, many studies have reported dominance of AS after clearcutting. For example, Brisson et al. [8] showed that in southern Quebec, AS rapidly dominated three clearcut stands after 17 to 50 years. Studies in north-eastern USA reported that AS was the dominant species 90 years [15], 65 years [26] and even 25 years [38] after a clearcut. Despite this evidence, these examples do not explicitly reveal whether the rapid return of AS after clearcutting is rare or frequent. However, our landscape-scale results demonstrate the return of AS after clear-cutting is clearly not an isolated event, but is quite common, especially when AS dominated pre-harvest composition. To our knowledge, our study is the first to document the capacity of AS to dominate stands after clear-cutting on such a large scale.

The period of time (40-70 years) over within which ASdominated stands developed after fire or clearcutting, which is much shorter than the age of senescence of recognized pioneer species such as trembling aspen and white birch, suggests that stand development did not involve a pioneer species stage before AS dominance. This result contradicts the commonly held notion that early successional species dominate after intense disturbance in temperate deciduous forests, to be subsequently replaced by slower growing, middle or late successional species $[8,13,17,27]$. However, our results are consistent with those of Merrens and Peart [34] and Castelli et al. [11], who showed that shade-tolerant hardwood stands which had experienced severe wind damage, rapidly recovered their pre-disturbance composition.

Furthermore, based on the successional status and shadetolerance rankings of AS and BA, several authors have concluded that BA should be initially favoured by large disturbances $[18,40]$, and later replaced by AS [21, 49]. Our results suggest the opposite, especially in the southern landscape. Indeed, early BA regeneration is often problematic during the

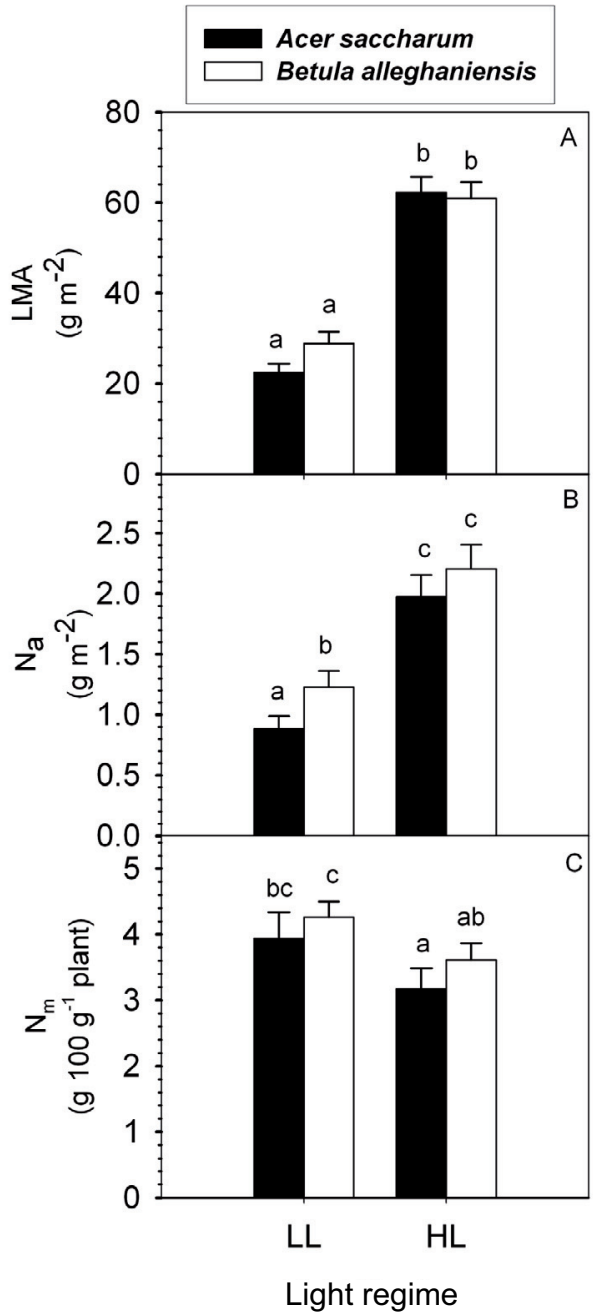

Figure 6. Means and standard errors for leaf mass area, LMA (A), nitrogen concentration on an area basis, $\mathrm{N}_{\mathrm{a}}$ (B) and nitrogen concentration on mass basis, $\mathrm{N}_{\mathrm{m}}$ (C) of 2 year-old Acer saccharum (AS; filled bars) and Betula alleghaniensis (BA; open bars) seedlings grown under two contrasting light regimes (low light (LL): $8 \%$ of external radiation and high light (HL): $45 \%$ of external radiation).

establishment and seedling stages [20,39], sometimes leading to low regeneration rates and even regeneration failure [49]. In contrast, AS regeneration (i) is prolific [25], (ii) can survive in the understory as a large seedling bank [25] and, (iii) may show relatively high growth under high light ([9] and see also below). These factors in combination shed light on why AS was more favoured after clearcutting than BA in the southern landscape. The ability of AS to dominate forest cover (especially compared to BA) was less pronounced in the northern landscape than in the southern landscape. This finding may reflect the fact that AS approaches the northern limit of its range in our study area, and that climate may be decreasing its competitive ability relative to BA. 


\subsection{Plasticity and acclimation of AS under contrasting light regimes}

Not surprisingly, under LL, AS seedlings showed numerous adaptations related to this species' well-recognized shade-tolerance $[2,25]$. These adaptations include conservative growth (i.e., smaller size and lower carbon accumulation), high allocation to coarse roots but low allocation to branches, flat crown morphology and low concentration of leaf nitrogen [16, 29, 47]. Nevertheless, under HL, AS showed greater height growth than BA, a species typically ranked as intermediate in shade-tolerance, while having a similar total biomass accumulation. A particularly high allocation of biomass to the main stem (but not to branches) was responsible for the large increase in height for AS under HL. BA, on the other hand, allocated a large proportion of its biomass to branches, showing a relatively more balanced allocation to lateral and height growth. Under HL, AS also exhibited the long and narrow crown form associated with an efficient interception of direct and diffuse light [24, 37].

At the leaf level, it has been shown that AS displays traits that are suited to high irradiance for individuals regenerated from stump sprout after prescribed fires [30], as well as for natural seedlings [31]. In this study, AS did not show leaf traits especially well adapted to the HL regime. Rather, it showed values of leaf mass per area (LMA) and nitrogen content on an area $\left(\mathrm{N}_{\mathrm{a}}\right)$ and on a mass $\left(\mathrm{N}_{\mathrm{m}}\right)$ basis similar to $\mathrm{BA}$, a less shade-tolerant species present in earlier successional stages $[20,21]$. However, AS showed slightly higher leaf plasticity than BA in response to the contrasting light regimes, and such physiological plasticity, generally associated with pioneer or shade-intolerant species [5, 23, 44], suggests that to some extent, AS has an inherent ability to acclimate physiologically to high light.

Collectively, these results suggest that in addition to its capacity to acclimate to low light, AS is also competitive, at least with BA, under high light availability through a surprisingly high allocational, morphological and, to some extent, physiological plasticity.

\subsection{Revisiting the successional status of $\mathrm{AS}$}

Our findings do not of course rule out the widely demonstrated presence and abundance of AS at late-successional stages. However, this study demonstrates, at the landscape level, that AS is frequently favoured by severe disturbances. Moreover, our results at the scale of the individual tree shed light on the morphological and allocational traits this species possesses that allow it to respond well to severe disturbances.

Our results lead us to question the criteria that are used to attribute a successional status to a given species. Often, species characteristics such as seed production, growth under high light levels, or shade tolerance are used to define a species successional status. We believe, however, that the relative abundance of the species along the successional gradient is the clearest and most objective criterion. If a given species is more abundant at the beginning than at the end of the gradient, it should be considered an early successional species, and vice versa. For example, to designate $\mathrm{AS}$ as late-successional species because of its shade tolerance, or to designate it as an early-successional species because of its high seed production and height growth under high light levels may be misleading. Since AS can be abundant at both ends of the successional gradient, we propose that classifying it strictly as a late successional species is an oversimplification of its autecology and that generalist or trans-successional is a more appropriate designation for this species.

Many studies cited here contained information concerning the status of AS as a generalist or trans-successional species. However, because linkages could not be established across scales, most of these studies were not able to come to conclusions regarding the significance of the processes observed. This study thus underlines the importance of multi- and crossscale studies.

\section{CONCLUSION}

Up to now, most, if not all, studies dealing with the regeneration dynamics of AS were performed in closed canopy or old growth forests. Recognizing that AS can take advantage of severe canopy disturbances (especially on fertile sites) may encourage novel research dealing with its regeneration and development under much higher light availability than what has been studied to date. Currently, AS-dominated stands are mainly managed under uneven-aged systems across their native range. However, in a context of natural disturbance-based forest management, foresters should acknowledge the ability of AS to persist at several successional stages and avoid considering uneven-aged silviculture as the sole system of choice.

Acknowledgements: This project was partially financed by a grant from the program of "Mise en Valeur des Ressources du Milieu Forestier (Volet I)" from the Quebec Ministry of Natural Resources and Wildlife and FPS Canada Inc. The authors gratefully acknowledge Régis Pouliot for technical support, the staff of the national archives of Quebec at Gatineau for their collaboration in collecting historic information. The authors also thank Christian Messier and Erwin Dreyer for previous discussions concerning the individual scale study and Ronnie Drever for precious general and editorial comments. Data on the small saplings were obtained during the Ph.D. of S. Delagrange. For this study, the use of the nursery in France was made possible with the in-kind support of the INRA Nancy.

\section{REFERENCES}

[1] Arii K., Lechowicz M.J., The influence of overstory trees and abiotic factors on the sapling community in an old growth Fagus-Acer forest, Ecoscience 9 (2002) 386-396.

[2] Baker F.S., A revised tolerance table, J. For. 47 (1949) 179-181.

[3] Barbour M.G., Burk J.H., Pitts W.D., Terrestrial Plant Ecology, 2nd Ed., The Benjamin /Cummings Publishing Company, Inc., Menlo Park, CA, USA 1987, 634 p.

[4] Bazzaz F.A., The physiological ecology of plant succession, Ann. Rev. Ecol. Syst. 10 (1979) 351-371.

[5] Bazzaz F.A., Carlson R.W., Photosynthetic acclimation to variability in the light environment of early and late successional plants, Oecologia 54 (1982) 313-316. 
[6] Bonal D., Born C., Brechet C., Coste S.M.E., Roggy J.-C., Guehl J.-M., The successional status of tropical rainforest tree species is associated with differences in leaf carbon isotope discrimination and functional traits, Ann. For. Sci 64 (2007) 169-176.

[7] Bragg D.C., Roberts D.W., Crow T.R., A hierarchical approach for simulating northern forest dynamics, Ecol. Model. 173 (2004) 31-94.

[8] Brisson J., Bergeron Y., Bouchard A., Les successions secondaires sur sites mésiques dans le Haut-Saint-Laurent, Québec, Canada, Can. J. Bot. 66 (1988) 1192-1203.

[9] Canham C.D., Growth and canopy architecture of shade tolerant trees: response to canopy gaps, Ecology 69 (1988) 786-795.

[10] Cash D.W., Adger W.N., Berkes F., Garden P., Lebel L., Olsson P., Pritchard L., Young O., Scale and cross-scale dynamics: Governance and information in a multilevel world, Ecol. Soc. 11 (2006) [online]: http://www.ecologyand society.org/vol11/iss2/art8/.

[11] Castelli J.P., Brenda B.C., Sullivan J.J., Latham R.E., Early understory succession following catastrophic wind damage in a deciduous forest, Can. J. For. Res. 29 (1999) 1997-2002.

[12] Claveau Y., Messier C., Comeau P.G., Interacting influence of light and size on aboveground biomass distribution in sub-boreal conifer saplings with contrasting shade tolerance, Tree Physiol. 25 (2005) 373-384.

[13] Connell J.H., Slatyer R.O., Mechanisms of succession in natural communities and their role in community stability and organization, Am. Nat. 111 (1977) 1119-1144.

[14] Cooper S.D., Diehl S., Kratz K., Sarnelle O., Implications of scale for patterns and processes in stream ecology, Aust. J. Ecol. 23 (1998) 27-40.

[15] Crow T.R., Buckley D.S., Nauertz E.A., Zasada J.C., Effects on management on the composition structure of northern hardwood forests in upper Michigan, For. Sci. 48 (2002) 129-145.

[16] Delagrange S., Messier C., Lechowicz M.J., Dizengremel P., Physiological, morphological and allocational plasticity in understory deciduous trees: Importance of individual size and light availability, Tree Physiol. 24 (2004) 775-784.

[17] Drever C.R., Messier C., Bergeron Y., Doyon F., Fire and canopy species composition in the Great Lakes-St. Lawrence forest of Temiscamingue, Québec, For. Ecol. Manage. 231 (2006) 27-37.

[18] Dunn C.P., Guntensperger G.R., Dorney J.R., Catastrophic wind disturbance in an old-growth hemlock-hardwood forest, Can. J. Bot. 61 (1983) 211-217.

[19] Elliot K.J., Boring L.R., Swank W.T., Haines B.R., Successional changes in plant species diversity and composition after clearcutting a Southern Appalachian watershed, For. Ecol. Man. 92 (1997) 67-85.

[20] Erdmann G.G., Betula alleghaniensis Britton, Yellow Birch, in: Silvics of North America: Hardwoods, USDA Forest service, Washington, USA, 1990, pp. 133-147.

[21] Forcier L.K., Reproductive strategies and the co-occurrence of climax tree species, Science 189 (1975) 808-811.

[22] Franklin J.F., Spies T.A., van Pelt R., Carey A.B., Thornburgh D.A., Breg D.R., Lindenmaye, D.B., Harmon M.E., Keeton W.S., Shaw D.C., Bible K., Chen J., Disturbances and structural development of natural forest ecosystems with silvicultural implications, using Douglas-fir forests as an example. For. Ecol. Manage. 155 (2002) 399-423.

[23] Givnish T.J., Adaptation to sun and shade: A whole plant perspective, Aust. J. Plant Physiol. 15 (1988) 63-92.

[24] Givnish T.J., Plant stem: Biochemical adaptation for energy capture and influence on species distributions, in: Plant stems: Physiology and functional morphology, Academic press, San Diego, USA, 1995, pp. 3-49.

[25] Godman R.M., Yawney H.W., Tubbs C.H., Acer saccharum March, Sugar Maple, in: Silvics of North America: Hardwoods, USDA, Forest service, Washington, USA, 1990, pp. 78-91.

[26] Godman R.M., Books D.J., Influence of stand density on stem quality in pole-size northern hardwoods, USDA, Forest Service, North
Central Forest Experiment Station, St. Paul, MN, USA, Research Paper NC-54, 1971, $7 \mathrm{p}$.

[27] Horn H.S., The ecology of secondary succession, Ann. Rev. Ecol. Syst. 5 (1974) 25-37.

[28] Kimmins J.P., Forest ecology: A foundation for sustainable management, 2nd ed., Prentice Hall Inc., New Jersey, USA, 1997, 596 p.

[29] Kobe R.K., Carbohydrate allocation to storage as a basis of interspecific variation in sapling survivorship and growth, Oikos 80 (1997) 226-233.

[30] Kruger E.L., Reich P.B., Responses of hardwood regeneration to fire in mesic forest openings. II. Leaf gas exchange, nitrogen concentration, and water status, Can. J. For. Res. 27 (1997) 1832-1840.

[31] Lei T.T., Lechowicz M.J., Shade adaptation and shade tolerance in saplings of three Acer species from eastern North America, Oecologia 84 (1990) 224-228.

[32] Levin S.A., The problem of pattern and scale in ecology: the Robert H. MacArthur award lecture, Ecology 73 (1992) 1943-1967.

[33] McClure J.W., Lee T.D., Leak W.B., Gap capture in northern hardwoods: patterns of establishment and height growth in four species, For. Ecol. Manage. 127 (2000) 181-189.

[34] Merrens E.J., Peart D.R., Effects of hurricane damage on individual growth and stand structure in a hardwood forest in New Hampshire, USA, J. Ecol. 80 (1992) 787-795.

[35] Mladenoff D.J., He H.S., Design and behaviour of LANDIS, an object-oriented model of forest landscape disturbance and succession, in: Advances in spatial modeling of forest landscape change: approaches and applications, Cambridge University Press, Cambridge, UK, 1999, pp. 125-162.

[36] MRN, Norme de cartographie écoforestière, Forêt Québec, Direction des inventaires forestiers, Troisième programme de connaissance de la ressource forestière, Édition provisoire, ISBN : 2551-19159-2, 2000, $84 \mathrm{p}$.

[37] Niklas K.J., Plant biomechanics: An engineering approach to plant form and function, The University of Chicago Press, Chicago, USA, 1992, $607 \mathrm{p}$.

[38] Nyland R.D., Ray D.G., Yanai R.D., Briggs R.D., Zhang L., Cymbala R.J., Twery M.J., Early cohort development following even-aged reproduction method cuttings in New York northern hardwoods, Can. J. For. Res. 30 (2000) 67-75.

[39] Perala D.A., Alm A.A., Reproductive ecology of birch: A review, For. Ecol. Manage. 32 (1990) 1-38.

[40] Perala D.A., Alm A.A., Regeneration silviculture of birch: A review, For. Ecol. Manage. 32 (1990) 39-77.

[41] Poulson T.L., Platt W.J., Replacement patterns of beech and sugar maple in Warren Woods, Michigan, Ecology 77 (1996) 1234-1253.

[42] Robitaille A., Saucier J.-P., Paysages régionaux du Québec méridional, Les Publications du Québec, Québec, Canada, 1998, 213 p.

[43] Runkle J.R., Gap regeneration in some old-growth forest of the eastern United States, Ecology 62 (1981) 1041-1051.

[44] Valladares F., Wright S.J., Lasso E., Kitajima K., Pearcy R.W., Plastic phenotypic response to light of 16 congeneric shrubs from a Panamanian rainforest, Ecology 81 (2000) 1925-1936.

[45] Vester H.F.M., Tree temperaments, in: Tyree M.T., Nardini A., Salleo S., Labrecque M., L'arbre 2000, The tree, Ed. Somabec, Ste-Hyacinthe Qc, Canada, 2001, pp. 25-30.

[46] Walters M.B., Kruger E.L., Reich P.B., Growth biomass distribution and $\mathrm{CO}_{2}$ exchange of northern hardwood seedlings in high and low light: relationships with successional status and shade tolerance, Oecologia 94 (1993) 7-16.

[47] Walters M.B., Reich P.B., Trade-offs in low light $\mathrm{CO}_{2}$ exchange: a component of variation in shade tolerance among cold temperate tree seedlings, Funct. Ecol. 14 (2000) 155-165.

[48] Whitney G.G., An ecological history of the great lakes forest of Michigan, J. Ecol. 75 (1987) 667-684.

[49] Whittaker R.J., Willis K.J., Field R., Scale and species richness: towards a general, hierarchical theory of species diversity, J. Biogeogr. 28 (2001) 453-470. 